6. Надтока О. Ф. Географія : підруч. для 9 кл. загальноосв. навч. закл. / О. Ф. Надтока, О. М. Топузов. - К. : Вид. дім «Світ знань», 2009. - 224 с. 7. Пестушко В. Ю. Географія : підруч. для 9 кл. загальноосвіт. навч. закл. / В. Ю. Пестушко, Г. Ш. Уварова. - К. : Генеза, 2009. - 288 с. 8. Пестушко В. Ю. Географія : підруч. для 10 кл. загальноосвіт. навч. закл. рівень стандарту, авачем. рівень / В. Ю. Пестушко, Г. Ш. Уварова. - К. : Генеза, 2010. - 304 с. 9. Стадник О. Г. Економічна і соціальна географія України. 9 клас : посіб. для вчителя / Олександр Григорович Стадник. - Х. : Основа, 2009. - 126 с. - (Бібліотека журналу «Географія», Вип. 9 (69)). 10. Топузов О. М. Економічна і соціальна географія світу : підруч. для 10 кл. загальноосвіт. навч. закл. (профільн. рівень) / О. М. Топузов, Т. Г. Назаренко, Л. В. Тименко. - К. : Пед. думка, 2009. - 304 с. 11. Топузов О. М. Економічна і соціальна географія світу: підруч. для 10 кл. загальноосвіт. навч. закл. / О. М. Топузов, Л. В. Тименко. - К. : Зодіак-ЕКО, 2005. $208 \mathrm{c}$.

\title{
ВИКОРИСТАННЯ МІЖПРЕДМЕТНИХ ЗВ'ЯЗКІВ НА УРОКАХ БІОЛОГІЇ
}

Хороших О. В. Використання міжпредметних зв'язків на уроках біології.

У статті подано теоретичні відомості і практичні рекомендації щодо реалізації міжпредметних зв'язків на уроках біології, розглядаються проблеми використання міжпредметних зв'язків як засобу формування в учнів знань, обгрунтовуються щляхи збагачення навчальної та трудової діяльності дітей на основі міжпредметних зв'язків.

Ключові слова: міжпредметні зв'язки, інтеграція природничих наук, знання, системність навчання, оцінка, зацікавленість учнів, мислення, аналіз біологічних явищ і процесів.

Хороших О. В. Использование межпредметных связей на уроках биологии.

В статье содержатся теоретические сведения и практические рекомендации по осуществлению межпредметных связей на уроках биологии, рассматриваются проблемы использования межпредметных связей как способа формирования у учащихся знаний, обосновываются пути обогащения учебной и трудовой деятельности детей на основе межпредметных связей.

Ключевые слова: межпредметные связи, интеграция естественных наук, знания, системность обучения, оценка, заинтересованность учащихся, мышление, анализ биологических явлений и процессов.

Horoshyh O.V. The interdisciplinary communication on biology lessons.

The article provides theoretical information and practical advice on the implementation of interdisciplinary links in biology class. It considers the problem of using interdisciplinary links as a way of forming students' knowledge. The article substantiates the enrichment of children's learning on the basis of interdisciplinary links.

Key words: interdisciplinary links, integration of natural sciences, knowledge, systematic training, evaluation, interest of the students, thinking, analysis of biological phenomena and processes.

Міжпредметні зв'язки в навчанні відображають тенденції інтеграції науки та практики. Відбувається виникнення нових комплексних наук, які стають науковим фундаментом сучасного виробництва, прогресивних технологій. У зв'язку 3 цим 
особливго значення набуває здійснення міжпредметних зв'язків, які $є$ важливим засобом формування в учнів грунтовних знань і резервом удосконалення навчальновиховного процесу.

Сучасний підхід до вивчення біології неможливий без установлення міжпредметних зв'язків 3 іншими навчальними дисциплінами. На важливості реалізації міжпредметних зв'язків у процесі навчання наголошували Ф. Буслаєв, А. Дістервег, Я. Коменський, Д. Локк, І. Песталоцці, В. Стоюнін, К. Ушинський. У свій час цій проблемі багато уваги приділялося в роботах таких методистів-біологів, як: М. Верзилін, І. Звєрєв, Б. Комісаров, В. Корсунська, В. Максимова, М. Риков, І. Суравегіна, В. Федорова.

Проблемою опікувалися дидакти І. Лернер, М. Скаткін, Н. Лошкарьова, І. Батурін, В. Загвязанський, Н. Огурцов, Н. Піяшев, І. Федорець та інші. У низці наукових праць відзначається, що міжпредметні зв'язки сприяють формуванню в учнів світогляду, пізнавальних інтересів, розширенню їх світогляду, розвитку креативності.

Метою статті $є$ спроба виокремити основні підходи щодо використання міжпредметних зв'язків на уроках біології. Міжпредметні зв'язки $є$ ефективним засобом, що дозволяє об'єднати програмовий матеріал у струнку систему, творчо підійти до виконання тих завдань, які потребують знань 3 інших предметів, розглядати природні явища під іншим кутом зору, з погляду інших предметів, повніше і глибше розкрити зв'язки між біологією, хімією, фізикою, географією, суспільствознавчими предметами, тобто забезпечити підпорядкування окремого загальному.

У педагогічній практиці та методичній літературі наведено чимало прикладів, що узагальнюють психолого-педагогічну і світоглядну значущість міжпредметних зв'язків. Можна виокремити дві групи зв'язків. До першої відносяться зв'язки між близькими за змістом дисциплінами, що вивчаються за програмою у школах (між математикою та фізикою, фізикою та хімією, біологією та хімією, географією та біологією тощо). Подібні зв'язки зрозумілі для вчителів відповідних предметів і їх установлення не викликає будь-яких утруднень. До другої відносяться зв'язки між предметами, далекими за змістом (між біологією та математикою, біологією та історією, біологією та інформатикою тощо), встановлюються роздільні, прості, епізодичні зв’язки.

Міжпредметні зв'язки - це цільові та змістові збіги, що існують між навчальними предметами. Міжпредметні зв'язки становлять дидактичну умову, що сприяє піднесенню рівня науковості й доступності, активізації пізнавальної діяльності учнів, підвищенню якості знань, умінь i навичок. Реалізація міжпредметних зв'язків надає змогу економно i водночас інтенсивно використовувати час на уроках. Внутріпредметні зв'язки забезпечують системність у навчанні, демонструють ієрархічність його структури й активно впливають на засвоєння нових знань.

Психологи А. Ковальов, М. Поташник та А. Донців наголошували на особистісному впливі уроків 3 міжпредметним змістом. М. Скаткін так розглядав функцію міжпредметних зв'язків: «Формування загальної системи знань учнів про реальний світ, яка відображає взаємозв'язки різних форм руху матерії- одна з основних освітніх функцій міжпредметних зв'язків [7, с. 27]. Н. Піяшев акцентує увагу на тому, що «знання, які учні отримують на міжпредметній основі, стають головними в пізнавальній діяльності. Усе це підвищує продуктивність процесів мислення, зміцнює навички узагальнення, використання діалектичних методів аналізу явищ.

Отже, міжпредметні зв’язки виконують методологічну функцію в навчальному пізнанні, оскільки вони виражають узагальнену форму відношень між складниками навчальних предметів. У результаті формується новий спосіб мислення, вміння 
бачити загальне в окремому та окреме в загальному, аналізувати 3 позиції загального. Значною мірою усувається еклектичність знань, їх вузькоемпірична спрямованість» [2].

Методисти-біологи І. Звєрев, А. М'ягкова, М. Верзилін та інші виокремлюють три рівня міжпредметних зв'язків шкільної біології: теоретичний, емпіричний, практичний.

У змісті біологічної освіти важливо виокремити в загальному фонді наукових знань міжнаукові галузі, з якими має зв'язок біологія. В. Федорова наголошувала на взаємодії природничих наук: зв'язках шкільної біології з фізикою та хімією, які утворюють три групи:

а) ознайомлення з методами дослідження біологічних об'єктів;

б) пояснення біологічних процесів;

в) формування понять, які мають світоглядне значення.

Наприклад, зв'язки з курсом фізики встановлюються під час вивчення методів цитології, явище дифузії використовується під час пояснення надходження речовин у клітину тощо.

Як зазначив I. Батурін, особливо гостро відчувається різниця між біологією та хімією. Низка питань вивчення фізіології в 9 класі не забезпечується хімічною підготовкою учнів. Необхідно реалізувати опору на фізику та хімію під час вивчення молекулярної біології у 10 класі» [1, с. 26].

Реалізація міжпредметних зв'язків потребує ерудованості вчителя в суміжних галузях науки, методичних обговорень у колективі вчителів питань, загальних для циклу предметів, узгодженого планування уроків, пов'язаних із використанням міжпредметних зв'язків.

Б. Комісаров та І. Звєрев виявили такі методичні шляхи встановлення міжпредметних зв'язків:

1. Постановка запитань, відповідь на які потребує знань, набутих учнями у процесі вивчення інших предметів. Наприклад, чим пояснюється те, що життя тварин - це постійне протиборство з силами тяжіння? Чому поверхня тіла павуків, кліщів, комах вкрита тонким шаром воску?

2. Актуалізація навчального матеріалу 3 суміжних дисциплін, що вивчався раніше, для встановлення наступності у трактуванні біологічних понять i властивостей. Наприклад, повторення матеріалу 3 фізики допомагає учням відповісти на запитання: «Чому рибу важко утримувати в руках?», «Яка частина тіла риби бере основну участь у русі? Чому?».

3. Ознайомлення учнів з ідеями та деякими положеннями біоніки. Розповідь, що винахідливість природи не перестає дивувати інженерів, архітекторів, науковців, які наслідували іiі знахідки, повніше використали існуючі тисячоліттями біологічні конструкції та системи. Людина звертається за зразками до природи, вчиться у неї. Але фундаментальні дослідження рослин і тварин стали можливі у зв'язку з розвитком біології.

4. Проведення узагальнювальних уроків. На них заслуховуються повідомлення кількох учнів, підготовлених за рекомендованими вчителем темами, які мають світоглядне значення і потребують знань не тільки з біології, а й з інших предметів.

5. Розвиток пізнавальних інтересів учнів. Широке застосування міжпредметних зв'язків значною мірою допомагає сформувати у світогляді учнів дійсно наукову, матеріалістичну картину світу [5, с. 16, 34, 66].

Отже, міжпредметні зв'язки мають велике значення в розвитку світогляду учня, допомагають йому орієнтуватися в сучасних науках, і в біології зокрема. 
Дитина сприймає світ як єдність, цілісність здатна аналізувати, порівнювати, робити висновки.

Наведемо кілька прикладів використання міжпредметних зв'язків на різних етапах уроку:

1. Відстрочена відгадка: на початку уроку вчитель читає загадку (дивовижний факт), відгадка якої (ключик для розуміння) буде «відкрита» на уроці під час роботи над новим матеріалом.

У 1383 році в невеликому німецькому місті Вільснак коржики 3 пшеничного тіста, що залишилися у покинутій обгорілій церкві, покрилися кривавими плямами. Плями ці змили, але вони з'явилися знову в ще більшій кількості. Слух про це «диво» швидко розповсюдився. Церковники звалили провину на єретиків, почалося спалювання людей на багаттях. Як би ви пояснили причину появи плям?

Це приклад уведення в тему «Бактерії»; відгадка: у відповідних умовах бактеріїутворюють колонії на відповідному субстраті - пшеничному тісті; ці колонії були червоного кольору (Біологія - історія).

2. «Колесо майбутнього». Учням пропонується яка-небудь глобальна проблема, розв’язання якої вимагає від них міжпредметних знань: «Що відбудеться, якщо...». Учитель записує всі припущення на дошці, оформлюючи їх у схему причинно-наслідкових зв'язків (Зникнуть всі рослини на Землі? Зникнуть бактерії? Зникнуть запаси корисних копалин? тощо).

3. Навчальний мозковий штурм (НМШ): розв'язання творчої задачі організовується у формі НМШ. Учні тренують уміння стисло і чітко висловлювати свої думки, вчаться слухати і чути один одного. Методика проведення НМШ достатньо грунтовно описана в методичній літературі. Приклад завдання: знайдіть можливі причини вимирання динозаврів (біологія - географія - астрономія).

4. Технологія розв'язування дослідницьких задач (ТРДЗ). Дослідницькі (винахідницькі, відкриті, творчі тощо) завдання, що не мають прямої відповіді. На кольорових фотознімках, зроблених зі спалахом, зіниці очей людей часто виходять червоними. Це відбувається, якщо їх розмір у момент зйомки достатньо великий. Тоді значна кількість світла проникає в очне яблуко і відображається від його насичених кров'ю внутрішніх тканин. Як бути? (біологія - фізика: світлові явища).

5. Інтегровані завдання та запитання: учням пропонується завдання, яке можна розв'язати, використовуючи знання з інших предметів.

Робоча медоносна бджола за 1 хвилину відвідує до 12 квіток, а за день близько 7,2 тис. У великій бджолиній сім'ї буває до 50 тисяч робочих бджіл (у малій - близько 10 тисяч). Підрахуйте та запишіть, скільки квіток можуть опилити бджоли однієї бджолиної сім'ї протягом одного дня (біологія - математика).

Отже, спираючись на знання та інтереси учнів в галузі різних предметів, за допомогою встановлення міжпредметних зв'язків можна комплексно розв'язувати задачі освіти, розвитку та виховання учнів.

\section{Література}

1. Берман В. П. Межпредметные связи как средство активизации познавательной деятельности учащихся / В. П. Берман // Формирование умений и навыков в области познавательной деятельности в процессе изучения основ наук: тезисы матер. всес. научной конф.; [ред. кол. Коротяев Б.И. и др.]. - Ч. 2. - Славянск, 1974. - 82 с. 2. Большой психологический словар / сост. и общ. ред. Б. Мещеряков, В. Зинченко. - СПб. : Прайм - ЕВРОЗНАК, 2004. - 672 с. 3. Державна національна програма «Освіта» («Україна XXI століття»). - К. : Райдуга, 1994. - 61 с. 4. Волкова 3. Междисциплинарные взаимодействия: поиск путей решения в школе / 
3. Волкова, М. Занин // Биология в школе. - 1990. - № 6- С. 53. 5. Зверев И. Д. Общая методика преподавания биологии / И. Д. Звєрєв, А. Н. Мягкова. - . : Просвещение, 1985 - 191 с. 6. Петрова И. Педагогические основы межпредметных связей / И. Петрова. - М., 1985. - 79 с. 7. Скаткин М. Н. Проблемы современной дидактики / М. Н. Скаткин. - 2-е изд. - М. : Педагогика, 1984. - 96 с.

\section{Віктор Шутько}

\section{ПРОБЛЕМИ ФІЗИЧНОГО ВИХОВАННЯ ШКОЛЯРІВ ЧЕРЕЗ ПРИЗМУ ПОГЛЯДІВ УЧИТЕЛЯ}

Шутько В. В. Проблеми фізичного виховання школярів через призму поглядів учителя.

У статті розглядаються окремі проблеми сучасного фізичного виховання в школах промислового мегаполісу. Застосований метод анонімного анкетування серед учителів визначив їх професіональний потенціал, рівень і якість викладання предмету, відношення школярів до занять, підстави незадовільного здоров'я та фізичного розвитку школярів.

Ключові слова: учитель, фізичне виховання, професіоналізм, фізичний розвиток, мотив, рухова активність.

Шутько В. В. Проблемы физического воспитания школьников через призму взглядов учителя.

В статье рассматриваются отдельные проблемы современного физического воспитания в школах промышленного мегаполиса. Примененный метод анонимного анкетирования среди учителей определил их профессиональный потенциал, уровень и качество преподавания предмета, отношение школьников к знаниям, основания неудовлетворительного здоровья и физического развития школьников.

Ключевые слова: учитель, физическое воспитание, профессионализм, физическое развитие, мотив, двигательная активность.

Shutko V. V. Problems of physical education in schools in the light of the views of the teacher.

This paper discusses some problems of modern physical education in schools, industrial metropolis. The method of anonymous survey among teachers identified their professional capacity, level and quality of teaching the subject, the ratio of students to the knowledge bases of poor health and physical development of students.

Keywords: teacher, physical education, professionalism, physical development, tune motor activity.

Сучасний стан здоров'я, фізичного розвитку, фізичної підготовки та функціональних можливостей українських дітей турбує все доросле населення країни, починаючи 3 батьків, педагогів, медиків і завершуючи керівниками державних структур.

Ткачук С. [4, с. 307] на основі посилань на роботи Когут I. (2006), Круцевич Т.(2005), Бар-Ор О. (2009) та ін., причинами цих негативних фактів вбачає невідповідність рухової активності більшості школярів фізіологічним нормам, що забезпечують належний рівень фізичного стану дітей і підлітків. 